\section{Pharmaceutical compounds in drinking water}

\author{
Vikas Chander,' Bhavtosh Sharma, ${ }^{2}$ \\ Vipul Negi, ${ }^{3}$ Ravinder Singh Aswal, ${ }^{4}$ \\ Prashant Singh, ${ }^{1}$ Rakesh Singh, ${ }^{3}$ \\ Rajendra Dobhal ${ }^{5}$
}

'Department of Chemistry, DAV (PG) College, Dehradun, Uttarakhand; 2Uttarakhand Science Education and Research Centre (USERC), Dehradun, Uttarakhand; ${ }^{3}$ Department of Chemistry, DBS (PG) College, Dehradun, Uttarakhand; ${ }^{4}$ Department of

Environmental Sciences, Gurukula Kangri Vishwavidyalaya, Haridwar, Uttarakhand; ${ }^{5}$ Uttarakhand Council for Science and Technology (UCOST), Dehradun, Uttarakhand, India

\section{Abstract}

Pharmaceutical products and their wastes play a major role in the degradation of environment. These drugs have positive as well as negative consequences on different environmental components including biota in different ways. Many types of pharmaceutical substances have been detected with significant concentrations through various advanced instrumental techniques in surface water, subsurface water, ground water, domestic waste water, municipal waste water and industrial effluents. The central as well as state governments in India are providing supports by creating excise duty free zones to promote the pharmaceutical manufacturers for their production. As a result, pharmaceutical companies are producing different types of pharmaceutical products at large scale and also producing complex non-biodegradable toxic wastes byproducts and releasing untreated or partially treated wastes in the environment in absence of strong regulations. These waste pollutants are contaminating all types of drinking water sources. The present paper focuses on water quality pollution by pharmaceutical pollutants, their occurrences, nature, metabolites and their fate in the environment.

\section{Introduction}

The utilization of pharmaceutical drugs keeps rising due to improvement in health care system and expectations of people for longer life. The global utilization of different pharmaceutical drugs by human beings is about 1 lakh ton/year. This data reveals the worldwide average consumption of $15 \mathrm{gm} / \mathrm{capi}$ ta/annum. ${ }^{1,2}$ The large diversity of the human pharmaceuticals may be noticed by 12,000 approved (authorized) human pharmaceuticals. From environmental consideration, there are 850 active compounds in human pharmaceuticals. ${ }^{3}$ India has now emerged as one of the top five pharmaceutical markets of the world. As pharmaceutical industry is the leading science based industry in India, thus it contributes $1 \%$ of the country's total gross domestic product. ${ }^{4}$ Due to regularly increasing international demand, pharmaceutical industries are rapidly growing. This development of the pharmaceutical industries supplies over 65 countries and earns more than $50 \%$ revenue through exports. ${ }^{5}$ United States of America is the largest customer of Indian made drugs, which procured drugs worth Rs. 1.4 billion US dollar during the year $2007 .{ }^{6}$ The pharmaceutical industries consist of approximately 300 large scale and 8000 small scale organizations, producing thousands of formulations containing 350 different bulks of drug. ${ }^{4}$ Many pharmaceutical manufacturing units are rapidly increasing in India, ${ }^{7}$ which dispose-off their effluents into the stream either directly or after partial treatment. Therefore, proper management along with complete and effective treatment of pharmaceutical industrial wastes as well as of expired drugs is required to be undertaken with latest tools and techniques. The pharmaceutical drugs get excreted with urine and feaces as parental compound and as a number of its metabolites. The waste water of toilet is subsequently flushed with clean water, which is known as black water. This black water enters to the municipal sewer and ultimately enters the adjoining water bodies and may affect the water quality and aquatic life. ${ }^{8}$ The water pollution due to pharmaceutical wastes in Andhra Pradesh (India) has been reported to be about 150 times more than the highest level of pharmaceutical pollution in USA. ${ }^{5,-14}$ However, very few studies on pharmaceutical based water pollution have been carried out in India. The present paper highlights and reviews the impact of pharmaceutical pollutants on quality of water sources.

\section{Global pharmaceuticals market status}

Globally, the developed countries are main producers of pharmaceutical drugs. The five major countries in the world namely USA, Japan, Germany, United Kingdom and France are collectively two-third global pharmaceuticals manufacturers, while China and India are main global low cost producers of pharmaceuticals. Approximately 20,000 and 7500 pharma-
Correspondence: Bhavtosh Sharma, Uttarakhand Science Education and Research Centre (USERC), Dehradun, Uttarakhand, India.

E-mail: bhavtoshchem@gmail.com

Key words: Pharmaceutical effluent; pharmaceutical global market; fate and water pollution.

Received for publication: 22 January 2016 .

Revision received: 21 April 2016.

Accepted for publication: 25 April 2016.

This work is licensed under a Creative Commons Attribution NonCommercial 4.0 License (CC BYNC 4.0).

(O) Copyright V. Chander et al., 2016

Licensee PAGEPress, Italy

Journal of Xenobiotics 2016; 6:5774

doi:10.4081/xeno.2016.5774

ceutical units are running in India and China, respectively. ${ }^{15}$ However, the production of pharmaceuticals at global level as per continent wise is shown in Figure 1. India has progressively producing and consuming the pharmaceutical drugs. ${ }^{16}$ According to a recent Indian report, the Indian pharmaceutical market is expected to be US $\$ 55$ billion by the year 2020 among all third world countries. ${ }^{17}$ The European Federation of Pharmaceutical Industries and Associations (EFPIA) ${ }^{18}$ shows that Switzerland is the largest producer of pharmaceutical drugs in European continent. It produces pharmaceutical drugs worth 32,380 million $€$. Whereas, Latvia has the lowest production of these drugs worth only 108 million $€$. The Cyprus has market value and export of only 203 million $€$ and 223 million $€$, respectively. While, Germany has highest market value and export of 26,122 million $€$ and 50,818 million $€$, respectively. Similarly, the Belgium has imported pharmaceutical drugs of 26,757 million $€$. While, Cyprus has imported drugs of 237 million $€$. The statistical graph as depicted in Figure 2 represents country wise position in terms of production, market value, import and export respectively. ${ }^{18}$ In 1947 , the turnover of registered Indian pharmaceutical industries was Rs. 10 Crore. Now, it has increased up to US $\$ 5.5$ billion in 2004 with $17 \%$ annual growth rate. ${ }^{19}$

\section{Route of entry of pharmaceuti- cal compounds into water system}

Pharmaceutical substances are widely used for human and veterinary related health problems. More than hundreds of tonnes of pharmaceutical compounds are used in Austria, England and Germany collectively. ${ }^{20}$ According 
to an investigation, the consumption of pharmaceuticals i.e., 836 ton of acetylsacylic acid [non-steroidal anti-inflammatory drugs (NSAIDs) ], 622 ton of paracetamol (NSAIDs), 517 ton of metformin (antidiabetic), 345 ton of ibuprofen (NSAIDs), 88 ton of carbamazepine (antiepileptic) was found in Germany, where as 35 ton of naproxen (NSAIDs) was observed in England in year 2001.21 But due to incomplete metabolism these drugs excrete through defecation and urinary systems as unchanged form and still remain in sufficient concentration level. The discharge of treated, partially treated and untreated effluents of pharmaceutical industries in open areas as well as into the streams ${ }^{22}$ and unacceptable dispose of unused (i.e., expired drugs) ultimately contaminate various compartments of environment. ${ }^{23,24}$ These pharmaceutical residues may enter: i) in water supplies and soil through the excretion of animals and human beings: ii) in surface water through sewage treatment plants and agricultural runoff; and iii) in ground water through soil. ${ }^{25}$ In the world, United States of America and Europe have the most advanced and comprehensive waste treatment directives. ${ }^{26}$ In India, pharmaceutical industries discharge their treated and untreated effluents in open area and into streams. ${ }^{22}$ Due to change in the pharmaceutical production and effluents input characteristics, the treatment techniques are either inappropriate or inefficient. ${ }^{27}$ Pharmaceutical compounds have been found to enter the environment by different sources such as discharge of treated or untreated or partial treated industrial wastewater and improper disposal of expired or unused drugs etc..$^{23,24}$

\section{Regulations for monitoring the presence of drugs in environment}

The regulating authorities of pharmaceutical industries must require regular monitoring and enforcement of laws for proper disposal of pharmaceutical wastes for preventing environmental degradation. Central Pollution Control Board (CPCB) and State Pollution Control Boards (SPCBs) established by Water Act, 1974 and Water Cess Act, 1977 provided the option to tax water users violating regulations..$^{28}$ The CPCB has issued Minimum National Acceptable Standards (MINAS), according to which, SPCBs are required to enforce the laws for pharmaceutical industries. If the industry fails to comply with the Water Act, the SPCBs have authority to cut power supply, water supply, close the firm or even pursue public interest litigation before the Supreme Court. ${ }^{29}$

\section{Fate and occurrence of phar- maceuticals in environment}

The distribution of pharmaceutical products in the environment is mainly by aquatic medium followed by food-chain dispersal due to their low volatility. ${ }^{20}$ Although pharmaceuticals persist low in environment, they are ubiquitous in environment due to their higher rate of release as compared to the rate of transformation. ${ }^{30}$ Composition of sewage, weather conditions, design and operation of treatment plants determine the transformation of various active pharmaceutical products. ${ }^{31}$ The pharmaceutical products contaminated sludge, when used as an agricultural fertilizer can reach to the terrestrial environment and through chain it may enter into surface as well as ground water. $^{32}$ Pharmaceutical compounds can be efficiently removed from aqueous phase of waste water in a water treatment plant through several processes namely bio-degradation, sorption, stripping to air and abiotic transformation (photolytic degradation). Complete biodegradation, which results into carbon dioxide $\left(\mathrm{CO}_{2}\right)$ and water $\left(\mathrm{H}_{2} \mathrm{O}\right)$ is called mineralization. Incomplete or partial biodegradation includes the conjugation of the pharmaceutical and the degradation of a compound to a metabolite (also occurs in the human body). Conjugations of pharmaceuticals occur usually before excretion from human body. Due to this, compound becomes more polar and might excrete more easily from body. ${ }^{8}$ Ibuprofen, reached in the aquatic environment through metabolic process, has been studied by many researchers. The metabolism of ibuprofen leads to the formation of hydroxyl-ibuprofen (OH-Ibuprofen), carboxy ibuprofen (CAIbuprofen) and carboxy-hydratropic acid (CA-

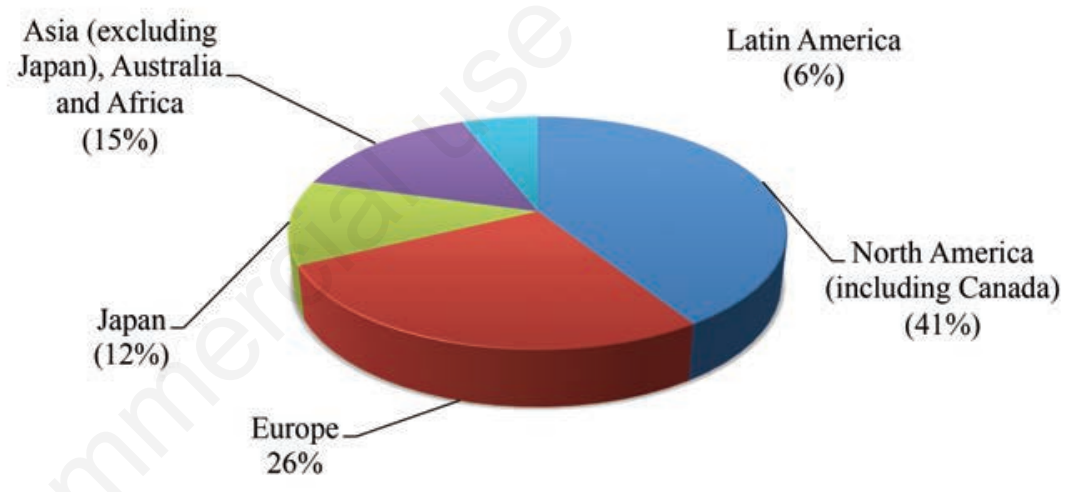

Figure 1. Status of global pharmaceuticals production continent wise.

$\Xi$ Production (in million $€$ ) $\square$ Market Value (in million $€$ ) $\boxminus$ Import (in million $€$ ) $₫$ Exports (in million $€$ )

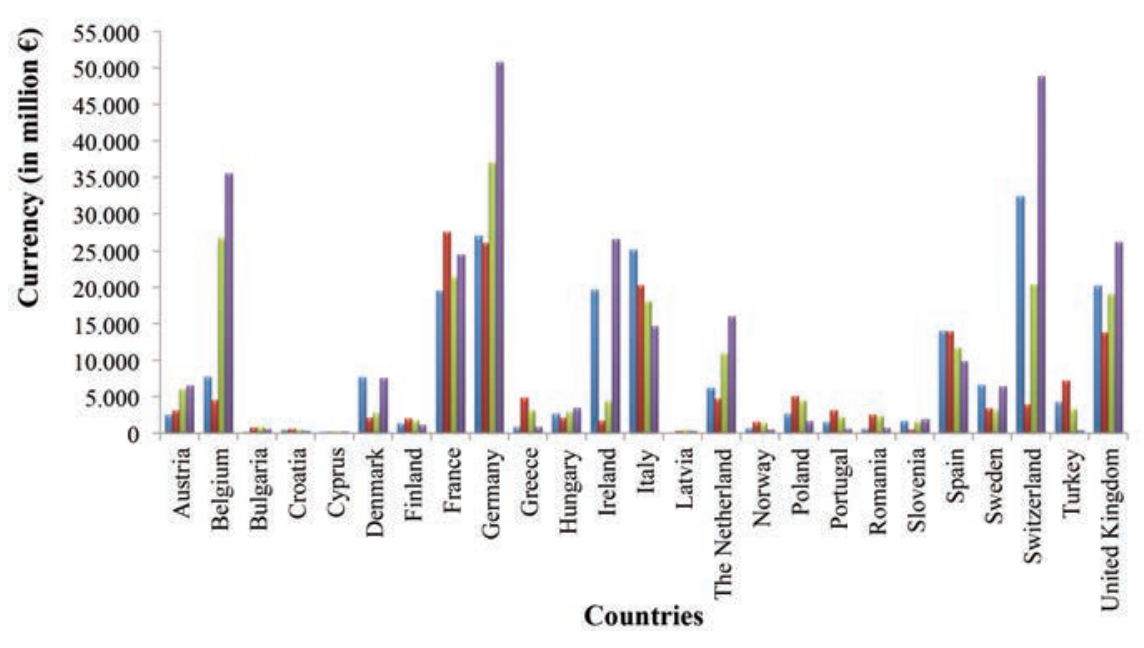

Figure 2. Statistical representation of pharmaceutical's market situation. 
AH) as 3 degraded products of ibuprofen. ${ }^{33}$ These metabolites are also formed during metabolism of ibuprofen in human body. The degradation process of ibuprofen ${ }^{34,35}$ is given in Figure 3.

The adsorption and complexation of pharmaceutical drugs in water or soil are still largely unidentified. Among studied anti-inflammatories and anti-blockers, most of them were removed less than $5 \%$, while some antibiotics can be even removed upto $90 \%$ by sorption technique onto sludge. ${ }^{36}$ Pharmaceutical compounds, particularly tetracyclines, have the propensity to sorb the soil particles or to form complexes with ions, which are present in the terrestrial ecosystem. ${ }^{37}$ Numerous pharmaceutical substances might have great impact on their behaviour in spite of being weak acids, weak bases, or zwitterions and site-specific water, soil, or sediment conditions viz. $\mathrm{pH}$, cation exchange capacity, etc. ${ }^{38}$ The sixty nine pharmaceutical drugs belonging to fifteen different therapeutic classes have been detected in more than effective concentration $(>0.1$ $\mu \mathrm{g} / \mathrm{L}$ ) in urban wastewater $0.10 \mu \mathrm{g} / \mathrm{L}-38.00$ $\mu \mathrm{g} / \mathrm{L}$ corresponding to salbutamol and acetaminophen, respectively. ${ }^{39}$

\section{Characteristics of pharmaceuti- cal drugs}

Many endocrine disrupting chemicals (EDCs) as synthetic organic chemicals like surfactants, pesticides, poly aromatic hydrocarbons, pharmaceuticals, brominated flame retardants, polychlorinated biphenyls and phthalates are being released in the environment through human induced activities. ${ }^{20}$ Generally, some pharmaceutical compounds have hydrophilic nature, whereas some have hydrophobic nature. But, the nature of some pharmaceuticals even varies as per environmental conditions. Besides, the nature of a pharmaceutical compound depends upon its chemical composition. Some of the pharmaceutical compounds with their nature have been provided in Table 1.

\section{Detection of pharmaceutical compounds in fresh water and wastewater samples}

In the past decade, the numbers of papers on the analysis of pharmaceuticals in drinking water samples have increased considerably. ${ }^{23,24,40}$ After 8 years period, a follow-up study has reconfirmed that pharmaceutical residues were still present in the water of adjoined areas. ${ }^{41}$ Several researchers have identified different types of pharmaceutical compounds in various types of water samples with specific extraction methods using highperformance liquid chromatography (HPLC), high-performance liquid chromatography coupled with mass spectrometry (HPLC-MS), high-performance liquid chromatography coupled with tandem mass spectrometry (HPLCMS/MS) etc. from $\mu \mathrm{g} / \mathrm{L}$ to $\mathrm{ng} / \mathrm{L}$ concentration ranges. ${ }^{42-45}$

\section{Pharmaceuticals in Indian drinking water}

Larsson and his group ${ }^{46}$ have reported the concentration $(90-31,000 \mu \mathrm{g} / \mathrm{L})$ of various drugs like metoprolol, enoxacin, enrofloxacin, citalppram, norfloxacin, lomefloxacin ciprofloxacin, losartan, cetirizine, ofloxacin and ranitidine in the effluent of sewage treatment plant in Patancheru Enviro Tech Ltd. (PETL) of Patancheru, in Hyderabad.

The pharmaceutical compounds with detected concentrations in ground and surface water have been summarized in Table $2 .{ }^{42-44}$ In another study, the average total concentration of detected pharmaceutical compounds was found $24 \mathrm{ng} / \mathrm{L}$ in each studied sample. While, antipyrine (analgesic) and sulfamethizole (antibiotic) were detected for first time in drinking water sources of USA. ${ }^{47}$ Fick et al. have reported the presence of drugs in the samples of wells, lakes and rivers of nearby areas of Hyderabad in India (Table 3). ${ }^{41}$ The authors found that all the wells were contaminated with drugs like Ciprofloxacin, enoxacin, cetrizine, terbinafine and citalopram in more than $1 \mu \mathrm{g} / \mathrm{L}$ concentration whereas higher concentration of ciprofloxacin $(6.5 \mathrm{mg} / \mathrm{L})$, norfloxacin $(0.52 \mathrm{mg} / \mathrm{L})$, enoxacin $(0.16 \mathrm{mg} / \mathrm{L})$ and cetirizine $(1.2 \mathrm{mg} / \mathrm{L})$ drugs were investigated in two lakes of the area using $\mathrm{C} 18$ column in HPLC instrument.

\section{Impact of pharmaceutical pol- lutants on water quality}

The effluents released from pharmaceutical industries consist of different chemical and biological compounds. Due to such nature, these effluents may lead changes in water quality. Out of all drinking water quality parameters, some characteristics viz. $\mathrm{pH}$, temperature, total solids, total dissolved solid (TDS), total suspended solid, chloride, oil and grease, biochemical oxygen demand (BOD) and chemical oxygen demand (COD) indicated higher pollution level in effluents of Taloja industrial area, Mumbai, India. ${ }^{48,49}$ In Patancheru industrial area, Medak (India), the concentrations of TDS, BOD, COD, copper, arsenic, selenium, fluoride and iron were recorded 5 to 10 times higher than maximum permissible limit ${ }^{50,51}$ in waste water of inlet and outlet of a septic tank in pharmaceutical industrial area of Bangalore in India. However, several researches have focused on physicochemical characteristics and heavy metals analysis of pharmaceutical effluents in various parts of India and are summarized in Tables $4^{48,52-54}$ and $5 . .^{49,52,55,56}$

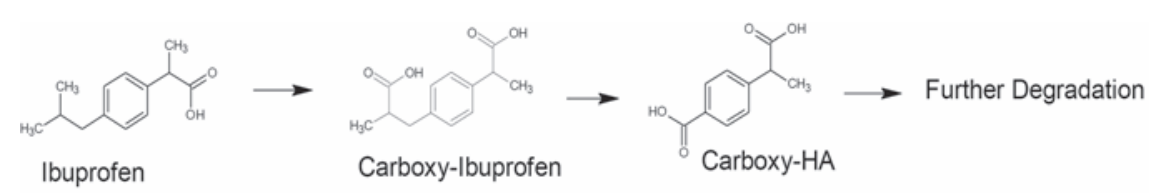

Figure 3. Oxidative metabolism of ibuprofen.

Table 1. Different classes and nature of pharmaceutical drugs.

\begin{tabular}{lcc} 
Pharmaceutical classes & Pharmaceutical drugs & Nature of pharmaceutical drug \\
Anti-inflammatory & Aspirin & Hydrophilic \\
& Diclofenac & Varies \\
Ibuprofen & Moderate hydrophobic \\
Lipid regulators & Clofibric acid & Moderate hydrophobic \\
& Bezafibrate & Hydrophobic \\
& Fenofibric acid & Hydrophobic \\
\hline Antiepileptics & Carbamazepine & Moderate hydrophobic \\
$\beta$-blockers & Metoprolol & Hydrophilic \\
Antibiotics & Ciprofloxacin & Hydrophilic
\end{tabular}

[Journal of Xenobiotics 2016; 6:5774]

[page 3] 


\section{Health impacts due to pharma- ceutical drugs present in fresh water and waste water}

Pharmaceutical compounds present in water bodies directly affect the user's health through respiratory disorders, cancers, reproductive problems, chronic depression and congenital problems including mental retardation and physical abnormalities, whereas indirectly by lowering productivity of agricultural land, altering agricultural infrastructure and leads to massive death of livestocks and fishes. ${ }^{57-59}$ Trace amount of pharmaceuticals in drinking water may cause considerable adverse effects to human health after long term exposure. The concentrations of pharmaceuticals detected in drinking water samples have numerous disorders. ${ }^{60}$ The release of EDCs into the environment may lead endocrine related diseases in the health of users, which are increasing in the wildlife and also changing the reproductive health of human beings includes declining male fertility, birth defects, breast and testicular cancer. ${ }^{20}$ EDCs also affect different hormones of the organisms. 17 -ethinylestradiol compounds are used as steroid estrogen analogue in the feminine pill and subsequently released in the environment through waste water treatment plant in the form of effluent. The predicted no-effect concentrations of the natural feminine hormones i.e., estrone, 17 estradiol, estriol were determined upto $6 \mathrm{ng} / \mathrm{L}$, $2 \mathrm{ng} / \mathrm{L}$ and $60 \mathrm{ng} / \mathrm{L}$ respectively, which is 20 to 600 times greater than the prescribed limit. The antineoplastics and immune modulating agents are responsible for genotoxic effects i.e., damage of DNA, cause cancer, etc. .1,62 $^{2}$

Pharmaceutical substances i.e., tamoxifen and cyclophosphamide used against breast cancer and ifosfamide, used for a large variety of cancer have already been detected in surface water. $^{31,61}$ It was also observed that all eukaryotic organisms are found to be susceptible to the pharmaceutical drug namely cytostatic. ${ }^{2}$ Caffeine works as metabolic stimulant and increase its effectiveness, when combined with medicines. ${ }^{20}$ However, Chiral pharmaceutical compounds can be a better option to reduce the load of pharmaceutical dosages to the patients and to protect the drinking water resources from unnecessary impact of pharmaceutical drugs. ${ }^{63,64}$

\section{Conclusions}

The pharmaceutical drugs and their metabolites are being found with increasing concentrations in aquatic as well as in terrestrial ecosystems. Due to continuous release of pharmaceutical compounds through different anthropogenic ways in significant amount, the impacts of drugs are increasing and affecting the environment. In recent years, the development of advanced and sophisticated analytical instruments has enabled scientists to detect the concentrations of these drugs upto ppm and ppb levels and even lower. Present study focuses on global production, occurrences, fate, properties, toxicity, chemical compositions, behaviour patterns and health hazards of these drugs on environmental components and other living beings. The study highlights the need of development of new techniques to safeguard the society from adverse health related acute and chronic effects of drugs. Pharmaceutical based environmental pollution has become an international issue, which requires due attention and changes in policies and regulations. Thus, detailed studies and

Table 2. Pharmaceutical compounds with detected concentrations in different water bodies with their extraction methods.

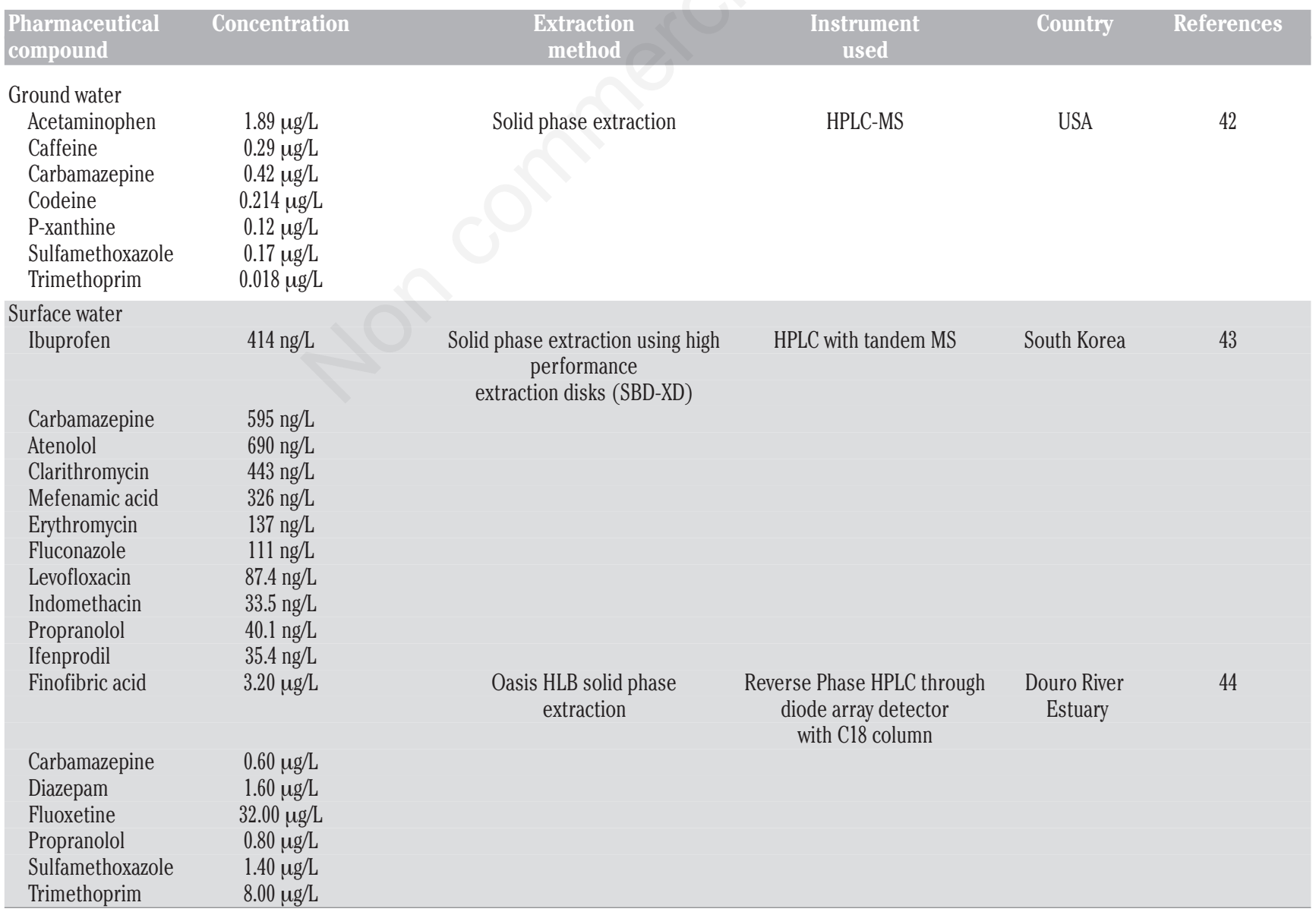

HPLC-MS, high-performance liquid chromatography coupled with mass spectrometry; 
Table 3. Detection of pharmaceuticals in fresh water samples in Hyderabad area, India.

\begin{tabular}{lccc}
\hline Drug & Lakes ( 03 sampling sites of 02 lakes) & River (06 sampling points) & Wells (06 wells) \\
Norfloxacin & $60,000-520,000$ & ND-4700 & ND-31 \\
Ciprofloxacin & ND-6,500,000 & $10,000-2,500,000$ & $44-14,000$ \\
\hline Ofloxacin & ND-11,000 & $180-10,000$ & ND- 480 \\
Enoxacin & $14,000-160,000$ & ND- 66,000 & ND-1900 \\
\hline Enrofloxacin & ND-25,000 & ND- 30,000 & ND- 67 \\
Metoprolol & $7000-N D$ & ND- 240 & ND- 90 \\
Cetirizine & $5000-1,200,000$ & $5,400-530,000$ & $550-28,000$ \\
Citalopram & $2000-8000$ & ND- 76,000 & ND- 1400
\end{tabular}

ND, not detected.

Table 4. Physico-chemical characteristics in pharmaceutical industrial effluents.

\begin{tabular}{|c|c|c|c|c|c|c|}
\hline S. No. & Characteristics & Unit & Ref. 48 & Ref. 52 & Ref. 53 & Ref. 54 \\
\hline 1. & $\mathrm{pH}$ & - & 5.1 & 12.54 & 10.34 & 8.00 \\
\hline 2. & Temperature & ${ }^{\circ} \mathrm{C}$ & 29.8 & - & 36.34 & 28.87 \\
\hline 3. & Conductivity & $\mu \mathrm{S} / \mathrm{cm}$ & - & 27,400 & 1534.21 & 1733.13 \\
\hline 4. & TSS & $\mathrm{mg} / \mathrm{L}$ & 654 & 2980 & 2673.22 & 348.75 \\
\hline 5. & TDS & $\mathrm{mg} / \mathrm{L}$ & 3412.5 & 8741 & 2655.43 & 873.81 \\
\hline 6. & DO & $\mathrm{mg} / \mathrm{L}$ & - & $3.50-4.70$ & 8.43 & 5.78 \\
\hline 7. & BOD & $\mathrm{mg} / \mathrm{L}$ & 1083.5 & 546 & 341.11 & 52.13 \\
\hline 8. & COD & $\mathrm{mg} / \mathrm{L}$ & 2797.3 & 1271 & 698.11 & 218.42 \\
\hline
\end{tabular}

TSS, total suspended solid; TDS, total dissolved solid; DO, dissolved oxygen; BOD, biochemical oxygen demand; COD, chemical oxygen demand.

Table 5. Concentrations of heavy metals in pharmaceutical industrial effluents.

\begin{tabular}{|c|c|c|c|c|c|c|}
\hline S. No. & Characteristics & Unit & Ref. 49 & Ref. 52 & Ref. 55 & Ref. 56 \\
\hline 1. & Chromium & $\mathrm{mg} / \mathrm{L}$ & 30.6 & 0.57 & 2.34 & 0.31 \\
\hline 2. & Cadmium & $\mathrm{mg} / \mathrm{L}$ & 35.8 & - & ND & 0.55 \\
\hline 3. & Nickel & $\mathrm{mg} / \mathrm{L}$ & 33.6 & 0.43 & - & 0.12 \\
\hline 4. & Zinc & $\mathrm{mg} / \mathrm{L}$ & 26.8 & 3.31 & - & 1.3 \\
\hline 5. & Copper & $\mathrm{mg} / \mathrm{L}$ & 17.6 & 14.06 & 2.30 & 0.38 \\
\hline 6. & Lead & $\mathrm{mg} / \mathrm{L}$ & 21.7 & 0.42 & ND & 0.263 \\
\hline 7. & Iron & $\mathrm{mg} / \mathrm{L}$ & 10.4 & 18.93 & 19.38 & 19.38 \\
\hline
\end{tabular}

ND, not detected.

investigations are required to develop the sustainable and long term effective solutions in order to save the health of mankind, other living organisms and environment from any type of pharmaceutical related pollution.

\section{References}

1. Ternes TA, Joss A. Human pharmaceuticals, hormones and fragrances - The challenge of micropollutants in urban water management. London: IWA Publishing; 2006.

2. Kummerer K. Pharmaceuticals in the environment: sources, fate, effects and risks. Berlin, Heidelberg: Springer; 2004.

3. Derksen JGM, Rijs GBJ, Jongbloed RH. Diffuse pollution of surface water by phar- maceutical products. Wat Sci Technol 2004;49:213-21.

4. Vijay G. Systemic failure of regulation: the political economy of pharmaceutical and bulk drug manufacturing. In: Lofgren $\mathrm{H}$, ed. The politics of the pharmaceutical industry and access to medicines: world pharmacy and India. Hyderabad: Social Science Press; 2012.

5. KPMG International. The Indian pharmaceutical industry: collaboration for growth; 2006. Available from: http://www.in.kpmg.com/pdf/Indian\%20ph arma\%20outlook.pdf Accessed: June 10, 2014.

6. Mason M. World's highest drug pollution levels found in Indian stream; 2009. Available from: http://usatoday30.usatoday.com/tech/science/environment/200901-26-drug-india-stream_n.htm Accessed:
May 11, 2016.

7. Kumar A, Bisht BS, Joshi VD, Singh AK, Talwar A. Physical, chemical and bacteriological study of water from rivers of Uttarakhand. J Hum Ecol 2010;32:169-73.

8. SWITCH, Biodegradability and fate of pharmaceutical impact compounds in different treatment processes. Katarzyna KujawaRoeleveld, Els Schuman WU, Environmental Technology, Wageningen, The Netherlands. Sustainable water management in the city of the future 2014. Available from: http:/www.switchurbanwater.eu/outputs/pd fs/W41_GEN_RPT_D4.1.3_Biodegradability _and_fate_of_phamarceutical_compounds.pdf Accessed: May 11, 2016.

9. Reddy AGS, Boraa S, Ganji S. Hydrogeochemical characterization of contaminated groundwater in Patancheru industrial area, Southern India. Environ. 
Monit. Assess 2012;184:3557-76.

10. Mathew G, Unnikrishnan MK. The emerging environmental burden from pharmaceuticals. Econ Polit Week 2012;47:31-4.

11. Mike A. India's waterways: a toxic stew of pharmaceutical chemicals dumped from big pharma factories. Natural News; 2009. Available

from: http://www.naturalnews.com/025415.html Accessed: June 15, 2014.

12. Schertow JA. India's waterways used as dumping grounds for big Pharma; 2009. Available from: http://intercontinentalcry. org/indias-waterways-used-as-dumpinggrounds-for-big-pharma/ Accessed: June 20, 2014.

13. CBS Investigates. Indian stream a cocktail of drugs. CBS News; 2009. Available from: http://www.cbsnews.com/2100-202_1624752641.html Accessed: May 31, 2014.

14. Ryu A. Pharmaceutical pollution of water in India: international market failure. Harv Heal Pol Rev 2013;14:25-8.

15. World Health Organization. The world medicine situation report; 2004. Available from: http://www.who.int/medicines/ areas/policy/world_medicines_situation/e n/ Accessed: June 5, 2014.

16. Corporate Catalyst (India) PVT Ltd. A brief report pharmaceutical industry in India; 2012.

17. Corporate Catalyst (India) PVT Ltd. A brief report on pharmaceutical industry in India; July 2015. Available from: http://www.cci.in/pdfs/surveys reports/pharmaceutical-industry-inindia.pdf Accessed: April 07, 2016. file:///C:/Users/user/Desktop/pharmaceutical-industry-in-india.pdf assessed on 07/04/2016.

18. European Federation of Pharmaceutical Industries and Associations (EFPIA). The pharmaceutical industry in figures; 2014. Available from: http://www.efpia.eu/ uploads/Figures_2014_Final.pdf Accessed: May 11, 2016.

19. Mazumdar M. Performance of pharmaceutical companies in india, contributions to economics. Berlin, Heidelberg: SpringerVerlag; 2013.

20. Nikolaou A, Meric S, Fatta D. Occurrence patterns of pharmaceuticals in water and wastewater environments. Anal Bioanal Chem 2007;387:1225-34.

21. Fent K, Weston AA, Caminada D. Ecotoxicology of human pharmaceuticals. Aquat Toxicol 2006;76:122-15.

22. Chander V, Singh P, Sharma B, Upadhyay K, Singh R. Environmental and health hazards due to pharmaceutical effluents. Int J Phar Rev Res 2014;4:100-3.

23. Glassmeyer ST, Furlong ET, Kolpin DW, et al. Transport of chemical and microbial compounds from known wastewater dis- charge: potential for use as indicators of human feacal contamination. Environ Sci Techno 2005;39:5157-69.

24. Wu M, Atchley D, Greer L, et al. Dosed without prescription: preventing pharmaceutical contamination of our nation's drinking water. Natural Resources Defense Council (NRDC) White Paper; December 2009. Available from: https:/www.nrdc.org/sites/default/files/hea _10012001a.pdf

25. World Health Organization. Pharmaceuticals in drinking-water; 2011. Available from: http://www.who.int/ water_sanitation_health/publications/201 1/pharmaceuticals/en/ Accessed: June 5, 2014.

26. Beachey M. A pharmaceutical hazard. Pharmaceutical Technology; 2008. Available from: http://www.pharmaceutical-technology.com/features/feature 45434 Accessed: June 20, 2014.

27. Vijayalakshmi MSR, Deepa BS. Impact of Industrial effluent treatment on profitability of small and medium enterprises: a case study of Hyderabad bulk drug industry, Entrepreneurship and SMEs: Building Competencies. New Delhi: Macmillan Publishers; 2011.

28. Maria A. The costs of water pollution in India. Paris: CERNA; 2013. pp 30-31.

29. Central Pollution Control Board (CPCB). Minimal National standards: pharmaceutical manufacturing and formulation industry. New Delhi: CPCB; 1989.

30. Bendz D, Paxéus NA, Ginn TR, Loge FJ. Occurrence and fate of pharmaceutically active compounds in the environment, a case study: Hoje River in Sweden. J Hazard Mat 2005;122:195-204.

31. Roberts PH, Thomas KV. The occurrence of selected pharmaceuticals in wastewater effluent and surface waters of the lower Tyne catchment. Sci Tot Environ 2006;356:143-53.

32. Carlsson C, Johansson AK, Alvan G, Bergman K, Kuhler T. Are pharmaceuticals potent environmental pollutants? Part I: Environmental risk assessments of selected active pharmaceutical ingredients. Sci Tot Environ 2006;364:67-87.

33. Zwiener C, Seeger S, Glauner T, Frimmel FH. Metabolites from the biodegradation of pharmaceutical residues of ibuprofen in biofilm reactors and batch experiments. Anal Bioanal Chem 2002;372:569-75.

34. Buser HR, Poiger T, Muller MD. Occurrence and environmental behavior of the chiral pharmaceutical drug ibuprofen in surface waters and in wastewater. Environ Sci Technol 1999 33;2529-35.

35. Ali I, Singh P, Aboul E, Hassan Y, Sharma B. Chiral analysis of ibuprofen residues in water and sediment. Anal Lett 2009;42:
1747-60

36. Chevre N. Pharmaceuticals in surface waters: sources, behavior, ecological risk, and possible solutions. Case study of Lake Geneva, Switzerland. Wiley Interdisciplin Rev Water 2014;1:69-86.

37 . Kummerer K. The presence of pharmaceuticals in the environment due to human use-Present knowledge and future challenges. J Environ Manage 2009;90:235466 .

38. Brooks BW, Huggett DB, Boxall ABA. Pharmaceuticals and personal care products: Research needs for the next decad. Environ Toxicol Chem2009;28:2469-72.

39. Verlicchi P, Al Aukidy M, Zambello E. Occurrence of pharmaceutical compounds in urban wastewater: removal, mass load and environmental risk after a secondary treatment - A review. Sci Tot Environ 2012;429:123-55.

40. Bruce G Pleus R, Snyder SA. Toxicological relevance of pharmaceuticals in drinking water. Environ Sci Tech 2010;44:5619-26.

41. Fick J, Söderström H, Lindberg RH, Phan C, Tysklind M, Larsson DG. Contamination of surface, ground, and drinking water from pharmaceutical production. Environ Toxicol Chem 2009;28:2522-7.

42. Fram MS, Belitz K. Occurrence and concentrations of pharmaceutical compounds in groundwater used for public drinkingwater supply in California. Sci Tot Environ 2011;409:3409-17.

43. Kim JW, Jang HS, Kim JG, Ishibashi H, Hirano M, Nasu K. Occurrence of pharmaceutical and personal care products (PPCPs) in surface water from Mankyung river, South Korea. J Health Sci 2009;55: 249-58.

44. Madureira TV, Rocha MJ, Cass QB, Tiritan ME. Development and optimization of a HPLC-DAD method for the determination of diverse, pharmaceuticals in estuarine surface waters. J Chromato Sci 2010;48: 176-82.

45. Santos JL, Aparicio L, Callejon M. Occurrence of pharmaceutically active compounds during 1-year period in wastewaters from four wastewater treatment plants in Seville (Spain). J Hazard Mat 2009;164:1509-16.

46. Larsson DGJ, Pedro C, Paxeus N. Effluent from drug manufactures contains extremely high levels of pharmaceuticals. J Hazard Mater 2007:53:161-3.

47. Schaider LA, Rudel RA, Ackerman JM, Dunagan SC, Brody JC. Pharmaceuticals, perfluorosurfactants, and other organic wastewater compounds in public drinking water wells in a shallow sand and gravel aquifer. Sci Tot Environ 2014;468:384-93.

48. Lokhande RS, Singare PU, Pimple DS. Study on physicochemical parameters of 
waste water effluents from Taloja industrial area of Mumbai, India. Int $\mathrm{J}$ Eco 2011;1:1-9.

49. Lokhande RS, Singare PU, Pimple DS. Toxicity study of heavy metals pollutants in waste water effluent samples collected from Taloja industrial estate of Mumbai, India. Res Environ 2011;1:13-9.

50. Shivkumar K, Biksham G. Statistical approach for the assessment of water pollution around industrial areas: a case study from Patancheru, Medak district, India. Environ Mon Assess 1995;36:229-49.

51. Kavitha RV, Krishna MV, Makam R, Asith KA. Physicochemical analysis of effluents from pharmaceutical industry and its efficiency study. Int J Eng Res Appl 2012;2:103-10.

52. Singare PU, Dhabarde SS. Studies on pollution due to discharge of effluent from pharmaceutical industries of Dombivali industrial belt of Mumbai, India. Int Lett Chem Phys Astrol 2014;3:16-23.

53. Singh SN, Srivastava G, Bhatt A. Physicochemical determination of pollution in wastewater in Dehradun. Curr World Environ 2012;7:133-8.

54. Damodhar U, Reddy MV. Impact of phar- maceutical industry treated effluents on the water quality of river Uppanar, South east coast of India: a case study. Appl Water Sci 2013;3:501-14.

55. Sankpal ST, Naikwade PV. Heavy metal concentration in effluent discharge of pharmaceutical industries. Sci Res Rep 2012;2:88-90.

56. Ramola B, Singh A. Heavy metal concentrations in pharmaceutical effluents of industrial area of Dehradun (Uttarakhand), India Int J Environ Sci Res 2013;2:140-5.

57. Dhara T, Cherukupalli A. The cost of cheap medicines: antibiotic pollution in Patancheru 2010. Available from: http://anilcherukupalli.com/the-cost-ofcheap-medicines-antibiotic-pollution-inpatancheru/ Accessed: October 15, 2012.

58. Greenpeace. State of community health at Medak district; 2004. Available from: http://www.greenpeace.org/india/Global/in dia/report/2004/10/state-of-communityhealth-at-m.pdf Accessed: November 10, 2012.

59. Wang C, Wang H, Liu Y. Separation of aluminum and plastic by metallurgy method for recycling waste pharmaceutical blis- ters. J Clean Prod 2015;102:378-83.

60. World Health Organization. Water sanitation health. Information Sheet: Pharmaceuticals in drinking-water; 2013. Available from: http://www.who.int/water_sanitation_heal th/emerging/info_sheet_pharmaceuticals/en/index.html Accessed: 5 June, 2014.

61. Buerge IJ, Buser HR, Poiger T, Müller MD Occurrence and fate of cytostatic drugs cyclophosphamide and ifosfamide in wastewater and surface water. Environ Sci Tech 2006;40:7242-50.

62. Johnson AC, Jürgens MD, Williams R, Kümmerer K, Kortenkamp A, Sumpter JP Do cytotoxic chemotherapy drugs discharged into rivers pose a risk to the environment and human health? An overview and UK case study. J Hydrol 2008;348:16775.

63. Sharma B. Nature of chiral drugs and their occurrence in environment. J Xenobiotics 2014;4:2272.

64. Ali I, Gupta VK, Aboul-Enein HY, Singh P, Sharma B. Role of racemization in optically active drugs development. Chirality 2007;19:453-63. 